\title{
CESIS
}

Electronic Working Paper Series

Paper No. 98

\section{CORPORATE GOVERNANCE AND INVESTMENTS IN SCANDINAVIA \\ - ownership concentration and dual-class equity structure}

Johan E. Eklund

(JIBS and CESIS)

September 2007 


\title{
Corporate Governance and Investments in Scandinavia - Ownership Concentration and Dual-Class Equity Structure
}

\author{
Johan E. Eklund ${ }^{12}$ \\ Jönköping International Business School and the Royal Institute of Technology \\ P.O. Box 1026, SE-551 11 Jönköping, Sweden \\ +46-36-101744 \\ Johan.Eklund@jibs.hj.se
}

\begin{abstract}
Juridical-political theories suggest that legal origin (La Porta et al. (1997)) and political factors (Roe (2003)) matters for firm performance. In Scandinavia there are a number of legal practices, with common political roots, that impinge on the distribution of corporate control, which accordingly may affect firm performance. This paper examines the return on investments and the effects of ownership concentration in a large sample of listed Scandinavian firms. As a performance measure marginal $q$ developed by Mueller and Reardon (1993) is used. Marginal $q$ measures the marginal return on capital relative its cost of capital. This is a more appropriate measure of performance than Tobin's average $q$. The question of how ownership concentration affects managerial investment decisions is examined. A Scandinavian corporate governance feature is the wide spread use of vote-differentiation. How deviations from the one-share-onevote principle affects this ownership-performance relationship is analyzed.
\end{abstract}

JEL Codes: G 30, C 23, K22, L25

Keywords: Investments, Marginal $q$, Corporate Governance, Ownership Concentration, DualClass Shares.

\footnotetext{
1 Financial support from the Ratio institute and Föreningssparbankernas forskningsstiftelse is gratefully acknowledged.

${ }^{2}$ This paper was initiated during a six month visit to George Mason University, and subsequently benefited a great deal from valuable comments and suggestions given by a large number of people. In particular I'm grateful for comments provided by Robin H. Hansson. Furthermore I also greatly appreciate valuable discussions during seminars held at Jönköping International Business School. In particular I thank Åke E. Andersson and Agostino Manduchi for valuable insights and helpful comments.
} 


\section{Introduction}

The way in which corporations are governed has received popular attention in recent years due to a series of corporate scandals, such as for example the so-called "Skandia scandal" in Sweden, Paramlat in Italy or Enron in the US. These are cases where the management has misused corporate resources and failed to serve the interests of the owners. However, the importance of sound corporate governance institutions and practices is more fundamental, and goes deeper than merely preventing flagrant fraud and managerial deceitfulness. A growing body of literature shows that corporate governance has a much more profound affect on the efficiency of resource allocation $^{3}$.

In essence the corporate governance system in a country is the institutional framework that supports the suppliers of finance to corporations and enables firms to raise substantial amounts of capital (Shleifer and Vishny (1997)). By protecting suppliers of capital and safeguarding property, sound governance systems facilitate mobilization and allocation of capital to useful investments. Corporate governance systems take a central position in determining how efficient capital is channeled to productive investments. It can be argued that the corporate governance system in a country determines the speed of structural change and economic development by affecting allocation and reallocation of capital. The crucial question here is therefore whether managers of corporations are making good investments decisions or not. This paper looks at corporate governance and the rate of return on corporate investments in Scandinavia. In particular the structure of ownership and its effects on performance is examined.

Taking an outsider's view of Scandinavia, the corporate governance systems in the Scandinavian countries, Sweden, Finland, Norway and Denmark, arguably display more similarities than differences. The countries share a number of important features that make them unison in comparison to other countries. It has for example been hypothesized that the common origin of the legal systems in Scandinavia is still reflected in the quality of corporate governance (La Porta (1997)). Furthermore, Scandinavian firms are typically controlled by one single dominant owner and only a small minority of firms is characterized by dispersed ownership structure.

\footnotetext{
${ }^{3}$ For a review of the corporate governance literature see for example Shleifer and Vishny (1997), Morck et al. (2005) and Denis and McConnell (2003).
} 
Furthermore, the Scandinavian countries can be said to have a common political orientation, with strong social democratic traditions, which according to Roe (2003) matters for corporate governance.

Such apparent homogeneity of the Scandinavian countries in combination with the importance of well functioning corporate governance systems motivates a comparison of corporate returns and ownership structure in Scandinavia. The purpose of this paper is therefore twofold: First, the returns on investments made by the largest firms in Scandinavia are assessed. Secondly, the effect of ownership structure on investment decisions is examined, which may be an important factor explaining variation in performance and in returns on investments. How deviations from the oneshare-one-vote principle affect this ownership-performance relationship is analyzed.

The paper is organized in six sections. Relevant literature on investments, corporate governance and ownership is reviewed in section two. Section three derives the method employed and describes the data. In section four the return on corporate investments in Scandinavia are examined and assessed. The fifth section examines how ownership and the extensive use of dualclass shares affect investment decisions. Section six provides the conclusion. 


\section{Corporate control and investment}

Neoclassical investment theory suggests that investments are made up to the point where the marginal rate of return equals the opportunity cost of capital (see figure 1 in appendix 1). This would be the case in a friction free world without any informational asymmetries or agency problems. Capital would flow automatically to the most efficient use and thereby guarantees that welfare is maximized. However, the rise of the modern corporation, with its separation of owners and financiers from the management, has created a set of agency problems that can cause investment decisions to deviate from what is expected from neoclassical models (see Mueller (2003) for a review of investment theories).

The modern corporation emerged in the early $18^{\text {th }}$ century as a tool for financing ventures that were too large for any single investor to be able or willing to supply all the necessary capital, but it also meant that the investors handed over most of the decision making to managers. Thus a classical principal agent dilemma arose as a direct corollary of this partition of decision-making process and supply of capital. This was observed already, at the very dawn of the modern corporation, by Adam Smith, who wrote that: "The directors of such companies, however, being the managers rather of other people's money than of their own, cannot well be expected, that they should watch over it with the same anxious vigilance with which the partners of a private copartnery frequently watch over their own." Adam Smith (1776).

In the absence of agency problems, investment decisions and firm performance should be expected to be independent from the structure and concentration of ownership. However, if agency problems can be attributed to the fact that firms are incorporated one should no longer expect firm value and investment decisions to be independent from ownership structure and concentration. Among the first to call attention to the potential agency costs ${ }^{4}$ were Berle $\&$ Means (1932). They argued that corporate ownership would become dispersed up to a point where professional managers would become unaccountable to the shareholders. Later, Jensen \& Meckling (1976) provide a more theoretical underpinning to the linkages between agency costs

\footnotetext{
${ }^{4}$ Agency costs are costs that arise from the principal-agent problem, i.e. divergence of managerial objectives from the objectives of shareholders.
} 
and ownership structure. Jensen and Meckling analyse how the interests of utility maximizing owner-managers and minority shareholders diverge as ownership structure becomes more dispersed. Their basic argument is that the owner-manager will not bear the full cost of on-thejob-consumption ${ }^{5}$. Potential minority investors will realize this and subsequently the share price will reflect the divergence of interest between owner-managers and minority shareholders. Arguably the conflict of interests becomes more severe as owner-managers equity stake decreases. They argue that investors with high stakes will also have strong incentives to maximize firm value. This is referred to as the incentive effect. Hypothesis one is therefore:

H1: Ownership concentration will reduce agency conflicts and thereby improve investment performance.

In this view agency costs increase as ownership is diluted and becomes dispersed. However, not all have seen the separation of ownership and control as a potential problem, where the counter hypothesis is that control and ownership separation may improve allocate efficiency. Thorstein Veblen (1921), for example, argues that this separation would lead to that the control would be turned over from "monopoly" seeking owners/businessmen to growth and efficiency seeking management. Veblen claims for example that if “(...) industry were completely organized as a systemic whole, and were then managed by competent technicians with an eye single to maximum production of goods and services; instead of, as now, being manhandled by ignorant business men with an eye single to maximum profits; the resulting output of goods and services would doubtless exceed the current output by several hundred per cent." (Veblen (1921)

Recognizing that owner-managers are also guided by utility maximization and not pure profit maximization, Demsetz (1983) argues that it is not clear that diffusion of ownership automatically will have a detrimental effect. In fact, it has been argued that as the stake of ownermanagers increase, so does their ability to misallocate resources also increase. This effect is referred to as the entrenchment effect. Expecting entrenchment effects leads to the second hypothesis.

\footnotetext{
${ }^{5}$ Jensen and Meckling (1976) also point out that the most serious problem of not having equity claims is probably that the incentive to seek new profitable investment opportunities and engage in innovative efforts will fall.
} 
H2: Ownership concentration will be associated with both positive incentive effects and negative entrenchment effect and ownership will as a consequence have a non-liner effect on performance.

The generality of Berle and Means observation can however be empirically questioned. Looking at ownership structure around the world most corporations have concentrated ownership and are controlled by families (Morck et al. (2005) and La Porta et al. (1999)).

Faccio and Lang (2002) study the ownership in Europe and find that corporations are predominantly controlled by families in continental Europe. This control is achieved without corresponding capital through using primarily three different control mechanisms: votedifferentiation of shares, pyramid ownership and cross-holdings. This means that the division of what Berle and Means (1932) call "nominal ownership" and the corporate control is further enhanced by separating the capital stake and voting power, making it possible for a small group of investors, often the founding family, to maintain the control of the firm.

Bebchuk et al. (1999) find that these control mechanisms distort the incentives of the controlling owners and therefore potentially may cause a sharp increase in agency costs. When the incentives are distorted this may potentially have a negative impact on the optimal choice of investments, scope of the firm and transferal of control. Separation of control rights and cash-flow right not only alters the control structure of the corporation but also changes the incentives of ownermanagers. An effect one can expect from the separation of cash-flow and control rights is that the positive incentive effect will be weakened whereas the entrenchment effect will be enhanced. From this hypothesis three follows:

H3: Control-mechanisms, such as dual-class equity structure, will through separation of control and cash-flow rights alter the incentives of controlling owners, and as a consequence the incentive effect will be weekend and the entrenchment effect will be enhanced. 
A large number of studies also establish a link between ownership structure and concentration on the one hand and performance on the other. Countries with weaker investor protection tend to have more concentrated ownership structure (see for example La Porta et al. (1997)). In fact the two most common ways of dealing with the agency aspects of corporate governance are, according to Shleifer and Vishny (1997), first legal and regulatory protection of investor and minority rights, and secondly large and concentrated owners. Outright expropriation of corporate assets and investor funds by managers is likely to be small in developed economies such as the Scandinavian ones. Overinvestment in pursuit of other ends than profit maximization and misallocation of assets is more likely to be a problem.

\subsection{Corporate Governance in Scandinavia}

The corporate governance systems in Scandinavia have some unique features that changes the prediction of the Jensen and Meckling model. Like most firms in continental Europe the Scandinavian firms very often controlling owners that have maintained their control even as their capital stake has declined and the firms have grown. Most European countries allow for at least one of the three principal instruments for control ownership: cross-holdings, pyramid ownership and vote-differentiation (Söderström et al. (2003)).

In particular the extensive use of vote differentiated shares has a substantial impact on the way in which the ownership structure has evolved in Scandinavia. In Norway about 14 percent of listed firms use dual-class shares, in Denmark and Finland more than 30 percent and in Sweden it is as high as 55 percent (Bøhren and Ødegaard (2005) and Söderström et al. (2003)). Many countries in Europe do not allow for dual-class share systems so this is one of the prominent distinguishing features of the corporate governance systems in Scandinavia. In Scandinavia the frequent use of dual-class shares with strong separation of voting rights and equity claims have produced very strong and stable ownership structures. By using vote-differentiation the founding families may retain control of firms even with a very small equity share. Most firms in Scandinavia have one single controlling owner and very few firms are characterized by dispersed ownership. For a sample of 4096 European firms Bennedsen and Nielsen (2005) report significant differences in the frequency that control mechanisms are used (see table 1). 
Table 1, Corporate control mechanisms in European Countries

\begin{tabular}{llll}
\hline & Dual-class shares & Pyramid & Cross-holding \\
\hline Sweden & $\mathbf{0 . 6 2}$ & $\mathbf{0 . 2 7}$ & $\mathbf{0 . 0 1}$ \\
Switzerland & 0.52 & 0.06 & 0.00 \\
Finland & $\mathbf{0 . 4 4}$ & $\mathbf{0 . 0 7}$ & $\mathbf{0 . 0 0}$ \\
Italy & 0.43 & 0.25 & 0.00 \\
Denmark & $\mathbf{0 . 2 9}$ & $\mathbf{0 . 1 7}$ & $\mathbf{0 . 0 0}$ \\
UK & 0.25 & 0.22 & 0.00 \\
Ireland & 0.25 & 0.18 & 0.00 \\
Austria & 0.23 & 0.26 & 0.01 \\
Germany & 0.19 & 0.24 & 0.03 \\
Norway & $\mathbf{0 . 1 1}$ & $\mathbf{0 . 3 3}$ & $\mathbf{0 . 0 2}$ \\
France & 0.03 & 0.15 & 0.00 \\
Belgium & 0.00 & 0.27 & 0.00 \\
Portugal & 0.00 & 0.13 & 0.00 \\
Spain & 0.00 & 0.16 & 0.00 \\
& & & \\
European average & 0.24 & 0.20 & 0.01 \\
Scandinavian average & 0.37 & 0.21 & 0.01 \\
\hline
\end{tabular}

Source: Bennedsen \& Nielsen (2005)

An additional consequence of the strong separation of ownership claims and control is that the so-called market for corporate control (Manne (1965)) virtually does not exist in Scandinavia. Successful hostile bids are therefore very rare.

The supposed importance of strong and stable owners provides the prominent argument underpinning the Scandinavian legislation that allows for vote-differentiation of share and pyramid ownership. In this paper ownership concentration is measured as the share of capital and votes controlled by the largest owner (CR1 \& VR1) and the five largest owners (CR5 \& VR5). About 40 percent of the firms in the aggregate Scandinavian sample separate control and cashflow rights. See table 2. The ownership data has been collected from the annual reports for each firm. For ownership data at country level see appendix 2. 
Table 2, Ownership concentration in Scandinavia (2004)

\begin{tabular}{|c|c|c|c|c|c|c|}
\hline \multicolumn{7}{|l|}{ All firms } \\
\hline & Mean & Std. dev. & Min & Max & No. firms & Skewness \\
\hline Capital share one owner, CR 1 & 23.5 & 15.5 & 0.4 & 82.4 & 214 & 0.90 \\
\hline Capital share five owners, CR 5 & 44.8 & 19.6 & 1.5 & 95.1 & 214 & 0.33 \\
\hline Vote rights one owner, VR 1 & 29.4 & 19.7 & 0.4 & 89.3 & 211 & 0.89 \\
\hline Vote rights five owners, VR 5 & 52.0 & 22.6 & 1.5 & 96.5 & 211 & 0.08 \\
\hline \multicolumn{7}{|l|}{ Vote-differentiated firms } \\
\hline & Mean & Std. dev. & Min & $\operatorname{Max}$ & No. firms & Skewness \\
\hline Capital share one owner, CR 1 & 23.5 & 13.7 & 2.9 & 60.4 & 90 & 0.70 \\
\hline Capital share five owners, CR 5 & 47.4 & 19.0 & 9.4 & 93.8 & 90 & 0.43 \\
\hline Vote rights one owner, VR 1 & 35.8 & 20.3 & 4.6 & 89.3 & 88 & 0.73 \\
\hline Vote rights five owners, VR 5 & 64.8 & 19.8 & 18.6 & 96.5 & 87 & -0.33 \\
\hline \multicolumn{7}{|l|}{ Firms with one-share-one-vote } \\
\hline & Mean & Std. dev. & Min & $\operatorname{Max}$ & No. firms & Skewness \\
\hline Capital share one owner, CR 1 & 23.2 & 16.7 & 0.4 & 82.4 & 124 & 1.01 \\
\hline Capital share five owners, CR 5 & 42.9 & 19.9 & 1.5 & 95.1 & 124 & 0.32 \\
\hline Vote rights one owner, VR 1 & 23.2 & 16.7 & 0.4 & 82.4 & 124 & 1.01 \\
\hline Vote rights five owners, VR 5 & 42.9 & 19.9 & 1.5 & 95.1 & 124 & 0.32 \\
\hline
\end{tabular}

This means that ownership concentration is very high in Scandinavian listed firms compared to Anglo-Saxon countries in particular. Demsetz and Lehn (1985) examine the ownership structure in 511 large US firms. They report that on average the five largest owners together held 24.8 percent and the top 20 shareholders 37.7 percent. Frequently 20 percent is assumed to be more than enough to control a firm (See Morck et al. (2005)).

La Porta et al. (1997) have hypothesized that the legal origin of a country creates a path dependence that determines the efficiency of financial systems. In this respect Scandinavia can be regarded as being relatively homogeneous. Scandinavia has for example a long tradition of cooperation in drafting new legislation (Carsten (1993)). Interestingly, there are still important differences with respect to deviations from one-share-one-vote principle. Denmark, Finland and Sweden all allow dual-class shares. In Norway deviations from the proportionality principle needs government approval (Faccio and Lang (2002)). 


\section{Methodology}

This paper applies a method to appraise the rate of return on investments developed by Mueller and Reardon (1993), which essentially is a marginal version of Tobin's $q$. Tobin's $q$ is defined as the market value of a firm over the replacement cost of its assets, which translates to the averages return on total assets. The marginal version of Tobin's $q$, on the other hand, measures the return on investments, or the marginal return on capital (Mueller (2003)). It is thus a measure of what Tobin (1982) calls the "functional form" of stock market efficiency ${ }^{6}$. Marginal $q$ is also a more appropriate measure of performance since average $q$ for example contains infra-marginal returns ${ }^{7}$.

Marginal $q$ can be derived from the simple insight that any investments should ex ante be evaluated against the discounted present value of future cash flows that the investment generates. Obviously, only projects that have a positive net present value should be carried out. Consider an investment, $I_{t}$, made by a firm in period $t$. This investment generates cash flows, $C F_{t+j}$ in $j$ periods. The present value, $P V_{t}$, of this cash flow is as follows:

$$
P V_{t}=\sum_{j=1}^{n} C F_{t+j} /\left(1+i_{t}\right)^{j}
$$

where $i_{t}$ is the discount rate. This equation can be expressed in the following way, where $r_{t}$ can be regarded as a quasi-permanent rate of return:

$$
P V_{t}=I_{t} r_{t} / i_{t}
$$

\footnotetext{
${ }^{6}$ Functional Stock Market Efficiency is related but different from the standard term Market Efficiency. Functional efficiency refers to the way in which capital markets are allocating resources to the most efficient usage (Tobin (1982)). Morck et al. (2005) surveys a literature that show how the functional efficiency of capital markets depends on the structure of corporate control.

${ }^{7}$ When firms are price takers and perfectly competitive, marginal $q$ and average $q$ will be equal. Firms with market power will have a higher average $q$. For a derivation of the relationship between average $q$ and marginal $q$ see Hayashi (1982).
} 
For investments to be efficient from a shareholder perspective the investment being considered must generate future cash flows that, discounted to present value, equals or exceeds the investment cost.

The quotient $r / i$ is essentially a marginal version of Tobin's $q$ (Mueller (2003)) which measures the return on a marginal investment, and will therefore henceforth be referred to as $q_{m}$ (see figure 2 in appendix 1). Accordingly, equation 2 can be rearranged and expressed as follows:

$$
\frac{P V_{t}}{I_{t}}=r_{t} / i_{t}=q_{m, t}
$$

For investments to be meaningful the $P V_{t} \geq I_{t}$, this implies that $q_{m} \geq 1$. If firms are investing at a $q_{m}=1$, investments are efficient. This implies that there no further profitable investment opportunities (see figure 1 in Appendix 1). Whereas if $q_{m}<1$, firms are receiving a return on their investments that is less than the cost of capital, which only can be interpreted as overinvestment and an managerial failure of some sort.

At the end of period $t$ the market value of a firm may be decomposed into the market value in period $t-1\left(M_{t-1}\right)$, the present value of investments made in period $t\left(P V_{t}\right)$, the change in market value of the old capital stock $\left(\delta_{t}\right)$, and an error term for the errors the market may make in their evaluation of the firm $\left(\mu_{t}\right)$.

$$
M_{t} \equiv M_{t-1}+P V_{t}-\delta_{t} M_{t-1}+\mu_{t}
$$

By replacing $M_{t-1}$ in equation 4 in each subsequent period the following expression is obtained:

$$
M_{t+n}=M_{t-1}+\sum_{i=0}^{n} P V_{t+i}-\sum_{1=0}^{n-1} \delta_{t+i} M_{t+i}+\sum_{i=0}^{n} \mu_{t+i}
$$


In a single period the error in markets evaluation of the firm can be substantial, however assuming efficient markets the $E\left(\mu_{t}\right)=0$, and $E\left(\sum_{i=0}^{n} \mu_{t+i}\right)=0$. Thus, as $n$ grows the last term will approach zero. From equation 3 we get the following expression:

$$
q_{m}=\frac{\sum_{i=0}^{n} q_{m, t+i} I_{t+i}}{\sum_{i=0}^{n} I_{t+i}}=\frac{\sum_{i=0}^{n} P V_{t+i}}{\sum_{i=0}^{n} I_{t+i}}
$$

Using equation 5 this expression can be formulated in the following way:

$$
q_{m}=\frac{\left(M_{t+n}-M_{t-1}\right)}{\sum_{i=0}^{n} I_{t+i}}+\frac{\sum_{i=0}^{n} \delta_{t+i} M_{t+i-1}}{\sum_{i=0}^{n} I_{t+i}}-\frac{\sum_{i=0}^{n} \mu_{t+i}}{\sum_{i=0}^{n} I_{t+i}}
$$

This can be used to calculate a weighted average $q_{m}$ for each firm ${ }^{8}$.

Assuming that $q_{m}$ and $\delta$ both are constant over time and across firms, we can use equation 4 to estimate $q_{m}$ and $\delta$ directly. Taking equation 4 and subtracting $M_{t-1}$ from both sides we get:

$$
M_{t}-M_{t-1}=-\delta M_{t-1}+q_{m} I_{t}+\mu_{t}
$$

Dividing with $M_{t-1}$ we normalize the equation and get following empirically testable function:

$$
\frac{M_{t}-M_{t-1}}{M_{t-1}}=-\delta+q_{m} \frac{I_{t}}{M_{t-1}}+\frac{\mu_{t}}{M_{t-1}}
$$

\footnotetext{
${ }^{8}$ See Mueller and Reardon (1993) for a description of the methodology and account of the properties of $q_{m}$.
} 
Mueller and Reardon's (1993) methodology can be applied to test agency hypothesis. In contrast to the average Tobin's $q$ this method measures the marginal return on investments, which makes it more appropriate when testing agency hypothesis.

To study the effects of ownership structure or various institutional factors on investment decisions, measures of ownership may be added as interaction terms with $I_{t} / M_{t-1}$ in equation 9 . If interaction terms are added the functional form will be: $Y=\alpha+\beta_{1} X+\beta_{2} X Z$ and $q_{m}$ is the economic interpretation of the marginal effect $\left(\partial Y / \partial X=\beta_{1}+\beta_{2} Z\right)$. This method has been applied by Gugler and Yurtoglu (2003) and by Bjuggren et al. (2006). The equations estimated are of the following functional form:

$$
\frac{M_{t}-M_{t-1}}{M_{t-1}}=-\delta+\beta_{1} \frac{I_{t}}{M_{t-1}}+\beta_{2} Z_{1} \frac{I_{t}}{M_{t-1}}+\ldots+\beta_{i+1} Z_{i} \frac{I_{t}}{M_{t-1}}+\varepsilon_{i}
$$

where the Z's denote the explanatory variables. Thus, the marginal effect, $q_{m}$, of equation 10 is:

$$
q_{m}=\beta_{1}+\beta_{2} Z_{1}+\ldots+\beta_{i+1} Z_{i}
$$

The total market value of a firm is defined as the total number of outstanding shares times the share price at the end of year $t$, plus total debt. Investments are defined as follows:

$$
\begin{aligned}
I= & \text { After tax profit }- \text { Dividends }+ \text { Depreciation }+\Delta \text { Equity }+\Delta \text { Debt } \\
& +R \& D+\text { Advertising \& Marketing }
\end{aligned}
$$

The market and accounting data have been collected from Compustat Global database ${ }^{9}$. The firms included were listed at one of the four Stock exchanges in Scandinavia (Copenhagen Stock exchange in Denmark, Helsinki Stock exchange in Finland, Oslo Stock Exchange in Norway and Stockholm Stock Exchange in Sweden) between 1998 or 1999 until 2005, in total 292 firms

${ }^{9}$ Accounting data and market prices has been collected from Standard \& Poor's Compustat Global Database, 2006 version. Following variables have been collected from Compustat (mnemonics in brackets): after tax profit (IB), depreciation (DP) dividends (DVT), total debt (DT), research and development (XRD), market price (MKVAL), Advertising and marketing expenditures (XSGA), $\Delta$ equity (SSTK minus PRSTKC). 
(2004 observations). All figures have been adjusted by harmonized consumer price indexes to 2005 constant prices. The indexes used have been compiled by Eurostat. Naturally the standard caveats apply to the data.

To use equation 7 and calculate $q_{m}$ it is also necessary to determine the size of the deprecation rate $\delta$. That is, the rate at which the value of firm's assets is declining over time. According to Mueller and Reardon (1993) most estimates are around 10 percent. Naturally the actual depreciation rate varies across firms and industries depending on the asset specificity. Even within firms we have reason to believe that the depreciation rate differs across the capital stock.

Equation 9 has the advantage that no assumption regarding the size of $\delta$ is necessary. In empirical estimation of equation 9 the intercept $(\delta)$ will capture the depreciation rate plus any systematic changes in market valuations of the stock of old capital. The estimated $\delta$ has no bearing on the interpretation of $q_{m}$. 


\section{Corporate Return in Scandinavia}

This study covers 292 large Scandinavian firms that are listed at one of the four stock exchanges. This make up about 40 percent of all listed firms. In 2004 the top 100 of these 292 firms (25 largest in each country) accounted for approximately 42 percent of the total stock market capitalization (33 percent of GDP $)^{10}$. The firms approximately follow a rank-size distribution where the second largest firm is about half the size of the largest ${ }^{11}$.

For Scandinavia the estimated average marginal $q$, excluding the upper 95 percentile and the lower 5 percentile, is 1.19. This means that during the period 1999 until 2005 the Scandinavian firms had an average return on investments that was 19 percent above the cost of capital. However the median $q_{m}$ is 1.03 , which implies a return that is 3 percent above cost of capital. Neither the average $q_{m}$ nor the median $q_{m}$ give any reason to believe that Scandinavian firms are under performing. This is based on the assumption that the depreciation rate was 5 percent per annum. Equation 7 is sensitive to the choice of depreciation rate. Consequently, a more rapid deprecation will translate into a higher $q_{m}$, all else equal.

Investments as defined in this paper can be negative. This will be the case if a firm is making losses that are larger in absolute terms than new equity and debt. It is neither meaningful to ask what the returns on investment are if investments are negative, nor does equation 7 make any sense when investments are negative or equal to zero. Accordingly some firms have been excluded from table 3 .

\footnotetext{
${ }^{10}$ In 2004 there were a total of 796 listed firms in Scandinavia (194 in Denmark, 143 in Finland, 177 in Norway and 282 in Sweden).

${ }^{11}$ The formula $M_{i}=M_{1} / i$, where $M_{1}$ is the largest firm and $i$ the firm rank, approximates the size distribution of the firms in the sample.
} 
Table 3, Cumulative distribution of marginal $q$

\begin{tabular}{lrrrrrrr}
\hline \hline Denmark & & & & & & & \\
Range of $\boldsymbol{q}_{\boldsymbol{m}}$ & $\mathbf{1 9 9 9}$ & $\mathbf{2 0 0 0}$ & $\mathbf{2 0 0 1}$ & $\mathbf{2 0 0 2}$ & $\mathbf{2 0 0 3}$ & $\mathbf{2 0 0 4}$ & $\mathbf{2 0 0 5}$ \\
\hline$q_{m} \geq 2.00$ & 10 & 9 & 6 & 2 & 4 & 5 & 5 \\
$1.50 \leq q_{m}<2.00$ & 3 & 2 & 3 & 4 & 3 & 4 & 8 \\
$1.00 \leq q_{m}<1.50$ & 3 & 3 & 3 & 5 & 3 & 6 & 6 \\
$0.50 \leq q_{m}<1.00$ & 10 & 14 & 12 & 9 & 11 & 13 & 13 \\
$0.00 \leq q_{m}<0.50$ & 11 & 19 & 23 & 26 & 25 & 23 & 22 \\
$-0.50 \leq q_{m}<-0.00$ & 9 & 5 & 5 & 8 & 8 & 5 & 3 \\
$-1.00 \leq q_{m}<-0.50$ & 4 & 4 & 1 & 0 & 2 & 1 & 0 \\
$\quad q_{m}<-1.00$ & 4 & 4 & 6 & 6 & 4 & 4 & 2 \\
Number of firms & 54 & 60 & 59 & 60 & 60 & 61 & 59 \\
Number of $q_{m} \geq 1$ & 16 & 14 & 12 & 11 & 10 & 15 & 19 \\
Number of $q_{m}<1$ & 38 & 46 & 47 & 49 & 50 & 46 & 40 \\
\hline
\end{tabular}

\begin{tabular}{lrrrrrrr}
\hline Finland & & & & & & & \\
Range of $\boldsymbol{q}_{\boldsymbol{m}}$ & $\mathbf{1 9 9 9}$ & $\mathbf{2 0 0 0}$ & $\mathbf{2 0 0 1}$ & $\mathbf{2 0 0 2}$ & $\mathbf{2 0 0 3}$ & $\mathbf{2 0 0 4}$ & $\mathbf{2 0 0 5}$ \\
\hline$q_{m} \geq 2.00$ & 20 & 17 & 9 & 11 & 13 & 12 & 15 \\
$1.50 \leq q_{m}<2.00$ & 5 & 1 & 9 & 5 & 5 & 4 & 4 \\
$1.00 \leq q_{m}<1.50$ & 9 & 6 & 2 & 9 & 10 & 16 & 22 \\
$0.50 \leq q_{m}<1.00$ & 8 & 11 & 17 & 16 & 15 & 11 & 9 \\
$0.00 \leq q_{m}<0.50$ & 3 & 13 & 10 & 8 & 8 & 9 & 3 \\
$-0.50 \leq q_{m}<-0.00$ & 3 & 3 & 4 & 1 & 1 & 1 & 1 \\
$-1.00 \leq q_{m}<-0.50$ & 0 & 3 & 2 & 3 & 1 & 2 & 2 \\
$\quad q_{m}<-1.00$ & 3 & 4 & 5 & 5 & 6 & 4 & 3 \\
Number of firms & 51 & 58 & 58 & 58 & 59 & 59 & 59 \\
Number of $q_{m} \geq 1$ & 34 & 24 & 20 & 25 & 28 & 32 & 41 \\
Number of $q_{m}<1$ & 17 & 34 & 38 & 33 & 31 & 27 & 18 \\
\hline
\end{tabular}

\begin{tabular}{lrrrrrrr} 
Norway & & & & & & & \\
Range of $\boldsymbol{q}_{m}$ & $\mathbf{1 9 9 9}$ & $\mathbf{2 0 0 0}$ & $\mathbf{2 0 0 1}$ & $\mathbf{2 0 0 2}$ & $\mathbf{2 0 0 3}$ & $\mathbf{2 0 0 4}$ & $\mathbf{2 0 0 5}$ \\
\hline$q_{m} \geq 2.00$ & 23 & 19 & 13 & 8 & 12 & 17 & 23 \\
$1.50 \leq q_{m}<2.00$ & 5 & 6 & 3 & 4 & 6 & 5 & 7 \\
$1.00 \leq q_{m}<1.50$ & 7 & 10 & 15 & 10 & 13 & 15 & 9 \\
$0.50 \leq q_{m}<1.00$ & 5 & 3 & 7 & 15 & 7 & 3 & 2 \\
$0.00 \leq q_{m}<0.50$ & 0 & 4 & 2 & 3 & 4 & 4 & 2 \\
$-0.50 \leq q_{m}<-0.00$ & 1 & 3 & 1 & 2 & 0 & 0 & 0 \\
$-1.00 \leq q_{m}<-0.50$ & 1 & 0 & 3 & 0 & 0 & 0 & 1 \\
$\quad q_{m}<-1.00$ & 2 & 2 & 3 & 6 & 4 & 1 & 1 \\
Number of firms & 44 & 47 & 47 & 48 & 46 & 45 & 45 \\
Number of $q_{m} \geq 1$ & 35 & 35 & 31 & 22 & 31 & 37 & 39 \\
Number of $q_{m}<1$ & 9 & 12 & 16 & 26 & 15 & 8 & 6 \\
\hline
\end{tabular}

\section{Sweden}

\begin{tabular}{crrrrrrr} 
Range of $\boldsymbol{q}_{\boldsymbol{m}}$ & $\mathbf{1 9 9 9}$ & $\mathbf{2 0 0 0}$ & $\mathbf{2 0 0 1}$ & $\mathbf{2 0 0 2}$ & $\mathbf{2 0 0 3}$ & $\mathbf{2 0 0 4}$ & $\mathbf{2 0 0 5}$ \\
\hline$q_{m} \geq 2.00$ & 36 & 26 & 14 & 5 & 12 & 15 & 18 \\
$1.50 \leq q_{m}<2.00$ & 4 & 3 & 7 & 2 & 5 & 5 & 12 \\
$1.00 \leq q_{m}<1.50$ & 12 & 16 & 9 & 11 & 12 & 15 & 14 \\
$0.50 \leq q_{m}<1.00$ & 4 & 20 & 25 & 27 & 26 & 28 & 28 \\
$0.00 \leq q_{m}<0.50$ & 23 & 26 & 31 & 36 & 32 & 30 & 29 \\
$-0.50 \leq q_{m}<-0.00$ & 6 & 4 & 9 & 6 & 9 & 7 & 3 \\
$-1.00 \leq q_{m}<-0.50$ & 0 & 4 & 3 & 6 & 3 & 3 & 1 \\
$q_{m}<-1.00$ & 3 & 8 & 10 & 13 & 10 & 6 & 2 \\
Number of firms & 88 & 107 & 108 & 106 & 109 & 109 & 107 \\
Number of $q_{m} \geq 1$ & 52 & 45 & 30 & 18 & 29 & 35 & 44 \\
Number of $q_{m}<1$ & 36 & 62 & 78 & 88 & 80 & 74 & 63
\end{tabular}

Assuming $\delta=10$ percent. 
As can be seen from table 3, returns on investments are approximately normally distributed around a mean of one in all of the four Scandinavian countries, except Norway. As the estimated $q_{m}$ 's are cumulated over 1999 to 2005 the distribution seems to become more centered around one.

A few of these are extreme values that distort the average $q_{m}$ across firms. These are typically smaller firms that for some reason either have very high return on invested capital or a massive loss in market value. There are several plausible explanations for these extreme values. For example firms may introduce radical innovations that do not require any substantial investments, but nevertheless substantially increase firm value. For this reason the average $q_{m}$ is also calculated excluding 5 percent in both ends of the distribution.

Dropping 5 percent in both ends of the distribution, the average $q_{m}$ for Denmark is $0.76,1.27$ for Finland, 1.83 for Norway and 1.11 for Sweden. The median $q_{m}$ for Denmark is $0.57,1.18$ for Finland, 1.86 for Norway and 0.85 for Sweden. If the assumption that $\delta=10$ percent is approximately correct, this means that all four of the Scandinavian countries, with the exception of Denmark, have average returns equal or above the cost of capital.

Bjuggren and Wiberg (2006) have found that $q_{m}$ is sensitive to stock market swings and that depending on period selection the $q_{m}$ may either be over or underestimated. The choice of 5-6 year period therefore approximately coincides with the average length of a business cycle.

In table 4 marginal $q$ for the 10 largest firms in each Scandinavian country is reported. The first two columns report the total market values in 2005 and 1998 adjusted to 2005 constant prices (columns 1 and 2). Total investments made during this period are reported in column three. Since equation 7 is sensitive to choice of depreciation, $q_{m}$ has been calculated assuming 5,10 and 15 percent depreciation of old capital (columns 4, 5 and 6). Furthermore the implicit $\delta$ can be calculated from equation 7 by assuming that $q_{m}=1$. This implicit depreciation rate is reported in column 7 . 
Table 4, 10 largest companies in the Scandinavian countries 2005

\begin{tabular}{|c|c|c|c|c|c|c|c|}
\hline & 1 & 2 & 3 & 4 & 5 & 6 & 7 \\
\hline Company & $\mathrm{M}_{2005}{ }^{\mathrm{a}}$ & $\mathrm{M}_{1998}{ }^{\mathrm{a}}$ & $\sum I N V^{\mathrm{a}}$ & $\begin{array}{c}q_{m} \\
(\delta=5 \%)^{\mathrm{b}}\end{array}$ & $\begin{array}{c}q_{m} \\
(\delta=10 \%)^{\mathrm{b}}\end{array}$ & $\begin{array}{c}q_{m} \\
(\delta=15 \%)^{\mathrm{b}}\end{array}$ & $\delta^{\mathrm{c}}$ \\
\hline \multicolumn{8}{|l|}{ Denmark } \\
\hline A.P. MÖLLER - MAERSK & 47702.9 & 7211.4 & 27433.4 & 1.668 & 1.860 & 2.052 & -0.124 \\
\hline TDC & 13932.1 & 15676.0 & 12303.0 & 0.244 & 0.630 & 1.016 & 0.148 \\
\hline NOVO NORDISK & 13124.1 & 8752.7 & 17150.9 & 0.481 & 0.706 & 0.932 & 0.048 \\
\hline CARLSBERG & 6842.0 & 4706.6 & 19592.3 & 0.199 & 0.289 & 0.378 & 0.113 \\
\hline H. LUNDBECK & 3904.8 & $2607.8^{d}$ & 5400.0 & 0.515 & 0.790 & 1.065 & 0.138 \\
\hline DANISCO & 5105.6 & 3728.0 & 6866.8 & 0.395 & 0.590 & 0.784 & 0.205 \\
\hline WILLIAM DEMANT HOLDING & 3165.8 & 962.1 & 2303.6 & 1.288 & 1.620 & 1.951 & 0.007 \\
\hline COLOPLAST & 2486.8 & 1326.3 & 1998.2 & 0.869 & 1.157 & 1.444 & 0.073 \\
\hline COPENHAGEN AIRPORTS & 2479.6 & 1441.4 & 811.0 & 1.870 & 2.460 & 3.049 & -0.024 \\
\hline DE SAMMENSLUTTENDE & 2411.3 & 292.3 & 1215.6 & 1.972 & 2.201 & 2.430 & -0.162 \\
\hline \multicolumn{8}{|l|}{ Finland } \\
\hline NOKIA & 64861.2 & 68445.3 & 14966.5 & 0.619 & 1.293 & 1.966 & 0.078 \\
\hline STORA ENSO & 15108.7 & 13268.3 & 3364.9 & 0.690 & 1.214 & 1.739 & 0.080 \\
\hline UPM-KYMMENE & 13964.4 & 11361.0 & 1818.2 & 0.650 & 1.073 & 1.495 & 0.091 \\
\hline METSO & 4061.7 & 1415.5 & 16770.9 & 0.429 & 0.537 & 0.644 & 0.315 \\
\hline SANOMA-WSOY & 4050.2 & 789.6 & 658.2 & 2.072 & 2.517 & 2.963 & -0.070 \\
\hline M-REAL & 3914.6 & 2933.6 & 16027.0 & 0.476 & 0.752 & 1.029 & 0.014 \\
\hline RAUTARUUKKI & 3304.8 & 1953.9 & 1406.0 & 1.806 & 2.396 & 2.986 & -0.018 \\
\hline WARTSILA & 2752.5 & 1662.5 & 1287.0 & 1.770 & 2.381 & 2.993 & -0.013 \\
\hline TIETOENATOR & 2739.7 & 2298.9 & 2135.4 & 0.968 & 1.615 & 2.263 & 0.052 \\
\hline YIT CORP & 2589.4 & 409.8 & 662.4 & 3.530 & 3.902 & 4.275 & -0.289 \\
\hline \multicolumn{8}{|l|}{ Norway } \\
\hline NORSK HYDRO & 24942.5 & 12014.9 & 19283.6 & 0.986 & 1.302 & 1.617 & 0.052 \\
\hline ORKLA & 9539.4 & 5729.7 & 3582.9 & 1.698 & 2.332 & 2.967 & -0.005 \\
\hline NORSKE SKOGINDUSTRIER & 5043.3 & 2355.1 & 1477.6 & 1.573 & 1.599 & 1.624 & -1.050 \\
\hline HAFSLUND & 3135.1 & 1156.5 & 1823.6 & 1.448 & 1.811 & 2.174 & -0.012 \\
\hline FRED. OLSEN ENERGY & 2152.9 & 641.2 & 610.7 & 3.019 & 3.563 & 4.107 & -0.136 \\
\hline SCHIBSTED & 1900.9 & 1121.6 & 495.6 & 2.462 & 3.352 & 4.241 & -0.032 \\
\hline DNO & 1867.4 & 46.8 & 474.2 & 3.971 & 4.104 & 4.236 & -1.071 \\
\hline TOMRA SYSTEMS & 1056.9 & 1399.7 & 336.8 & 3.677 & 4.130 & 4.584 & -0.245 \\
\hline FARSTAD SHIPPING & 950.9 & 263.6 & 791.9 & 1.111 & 1.355 & 1.598 & 0.027 \\
\hline \multicolumn{8}{|l|}{ Sweden } \\
\hline ERICSSON & 49367.6 & 49661.1 & 62411.5 & 0.355 & 0.714 & 1.073 & 0.140 \\
\hline VOLVO & 24244.6 & 18240.9 & 32494.6 & 0.376 & 0.568 & 0.760 & 0.213 \\
\hline H \& M HENNES \& MAURITZ & 21244.0 & 15067.1 & 14736.6 & 0.825 & 1.232 & 1.638 & 0.071 \\
\hline ATLAS COPCO & 12599.3 & 5329.9 & 11514.7 & 0.850 & 1.069 & 1.287 & 0.084 \\
\hline SCA & 11652.2 & 7553.9 & 8847.4 & 0.860 & 1.257 & 1.654 & 0.068 \\
\hline SANDVIK & 11038.2 & 5502.1 & 12743.4 & 0.648 & 0.862 & 1.076 & 0.132 \\
\hline SCANIA & 9262.2 & 6128.1 & 11352.3 & 0.528 & 0.780 & 1.032 & 0.144 \\
\hline ELECTROLUX & 7426.0 & 9994.2 & 22765.3 & 0.019 & 0.150 & 0.281 & 0.424 \\
\hline SECURITAS & 6787.2 & 5421.3 & 7191.6 & 0.525 & 0.860 & 1.195 & 0.121 \\
\hline SKF & 5940.4 & 2348.3 & 7975.8 & 0.591 & 0.731 & 0.872 & 0.196 \\
\hline
\end{tabular}

${ }^{\mathrm{a}}$ Million Euros, 2005 constant prices, ${ }^{\mathrm{b}} q_{m}$ calculated assuming that $\delta$ is 5, 10 and 15 percent respectively,

${ }^{\mathrm{c}}$ Depreciation rate calculated given $q_{m}=1,{ }^{\mathrm{d}}$ market value 1999.

A few firms in table 4 have implicit deprecation rates that are negative, which indicates that these firms all had returns in excess of their cost of capital.

The dominant firm in Finland, Nokia, for example, has performed well over a long period and consequently has a $q_{m}$ around or slightly above one. This can be compared to the Swedish telecom firm Ericsson, one of Nokia's main competitors. Ericsson seems to have a lover $q_{m}$ given any depreciation rate, but remains approximately equal to one. It is plausible to assume that the differences in returns can be attributed to different performance since Nokia and Ericson can be 
assumed to have approximately the same depreciation rate. The dominant firm in Denmark, Moller-Mearsk with its high marginal q appears to be underinvesting. Finally, the dominating Norwegian firm Norsk Hydro seems to have a marginal $q$ approximately equal to one.

Assuming that the marginal rate of return $\left(q_{m}\right)$ and the depreciation rate $(\delta)$ are the same across companies and overtime these can be estimated by equation 9 . Since the data is cross-sectional time series, a panel fixed effect model is used as estimator (industry and time fixed effects model). The stock market may fail to make a correct valuation in a single period, but assuming efficient markets this error will approach zero as time span increases. To take the possibility for market errors into account, time dummies were used in the estimations. Both industry and time dummies are restricted to sum to zero, so that any effects measures the deviation from the average depreciation rate. The results are reported in table 5.

In order to remove outliers some of the observations have been removed from the data set. The absolute deviation between the dependent variable and the explanatory variable, $\left(\mid\left(\mathrm{M}_{\mathrm{t}}-\mathrm{M}_{\mathrm{t}-1}\right) / \mathrm{M}_{\mathrm{t}-1}\right.$ $\left.-\mathrm{I}_{\mathrm{t}} / \mathrm{M}_{\mathrm{t}-1} \mid\right)^{12}$, has been used to identify outliers. Observations that had an absolute deviation above two (41 observations) were removed. This captures for example firms that have large swings in market value without corresponding changes in investments. The excluded firms are predominantly found among relatively small hi-tech firms within the biotechnology and ICT sector. Bjuggren and Wiberg (2006) have shown that marginal $q$ measure is sensitive to swings in valuation of new high-tech firms.

\footnotetext{
${ }^{12}$ In practice this excludes observations that have missing observations, accounting errors et cetera. Observations that were excluded were only among the small firms in the sample.
} 


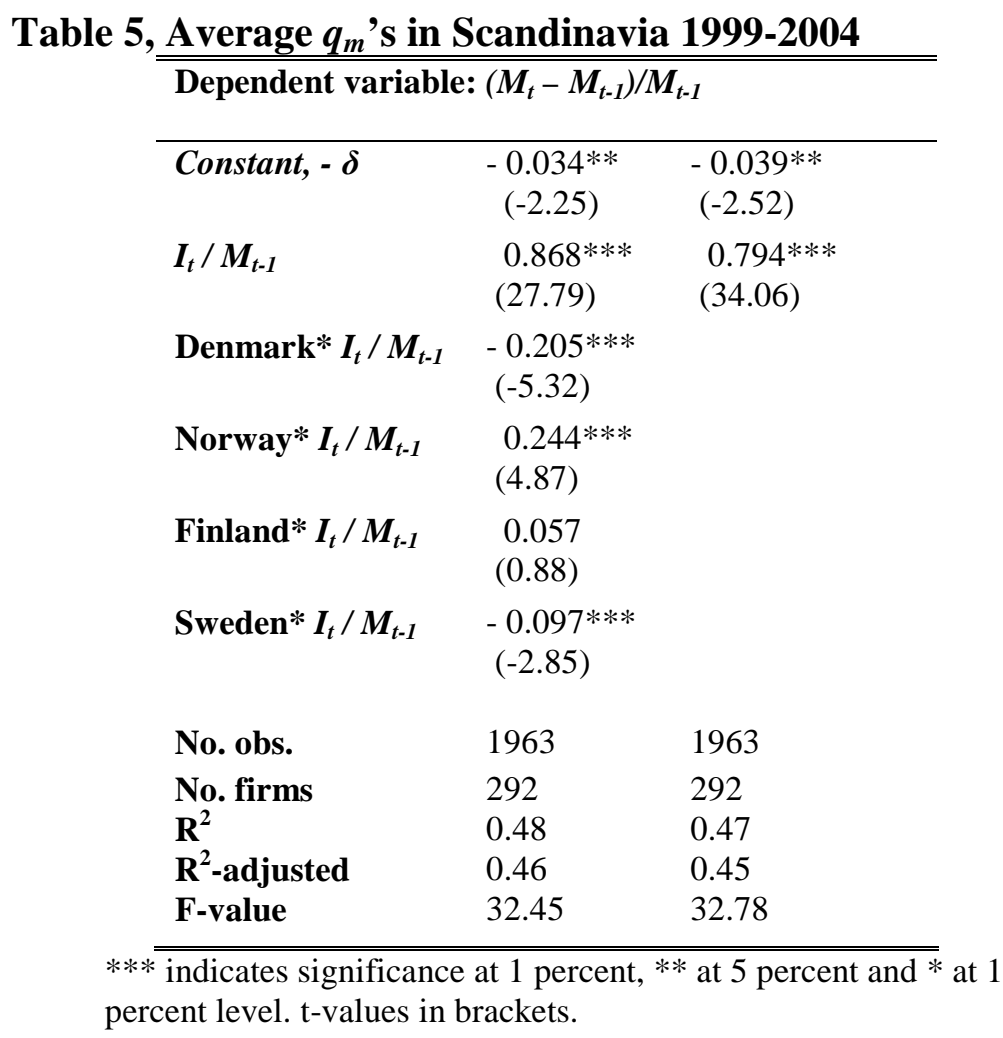

The regressions in table 4 were estimated with different intercepts, $-\delta$, for the different countries; these were however insignificant and were therefore dropped out of the regression. In order to test for country effects country dummy variables were interacted with $I_{t} / M_{t-1}$. These too were estimated under the restriction to sum to zero so that the country effects measures the deviation from the average Scandinavian marginal $q$. The Scandinavian average reported in table 5 is significantly below one. Marginal q for Denmark is $0.66,1.07$ for Norway, 0.93 for Finland and 0.77 for Sweden. These findings seem to collaborating previous estimates of marginal $q$ for the Scandinavian countries.

In a large cross-country study Gugler et al. (2002) find similar estimates for Scandinavia. Between 1985 and 2000 they estimate 0.65 for Denmark, 0.96 for Finland, 1.04 for Norway and 0.65 for Sweden. Bjuggren et al. (2006) have also estimated an average $q_{m}$ to 0.65 for Sweden. The findings reported in table 4 are in other words consistent with previous estimates for Finland and Norway. Gugler et al. (2002) have estimated the Scandinavian average at 0.78. Their findings 
support the legal origin hypothesis. Anglo-Saxon countries perform best with $q_{m}=1.02$. Average $q_{m}$ for Germanic and French origin is 0.74 and 0.59 respectively.

However there is considerable variation in the returns in all four Scandinavian countries, where a large number of firms deviate from the average marginal return on investments. This can have several causes, for example it might be plausible to believe there are industry differences. This is supported by the variation of the implicit deprecation rates in table 4.

In the following section the relationship between ownership concentration, separation of cashflow rights and control rights, and performance are examined. 


\section{Corporate return and ownership structure}

In this section equation 10 is used to test the effects of ownership concentration and separation of control from cash-flow rights on performance. As measures of ownership concentration, the share of capital (cash-flow rights) held by the largest owner ( $\boldsymbol{C R I})$ and the five largest (CR5) are used. Control rights are measured by the share of votes (control rights) held by the largest (VRI) and five largest owners (VR5). Dummies are used to control for dual-class shares. 49 percent of the firms in the sample use a dual-class share structure. Matching accounting and market data with the ownership data leaves 142 firms out of 292. Table 6 reports the correlations.

Table 6, Correlation matrix

\begin{tabular}{|c|c|c|c|c|c|c|c|}
\hline & Sales & $\mathrm{I}_{\mathrm{t}} / \mathrm{M}_{\mathrm{t}-1}$ & $\mathrm{M}_{\mathrm{t}}-\mathrm{M}_{\mathrm{t}-1} / \mathrm{M}_{\mathrm{t}-1}$ & CR1 & CR5 & VR1 & VR5 \\
\hline Sales & 1 & & & & & & \\
\hline $\mathrm{I}_{\mathrm{t}} / \mathrm{M}_{\mathrm{t}-1}$ & 0.012 & 1 & & & & & \\
\hline $\mathrm{M}_{\mathrm{t}}-\mathrm{M}_{\mathrm{t}-1} / \mathrm{M}_{\mathrm{t}-1}$ & -0.043 & $0.422 *$ & 1 & & & & \\
\hline CR1 & $-0.088 *$ & 0.069 & 0.033 & 1 & & & \\
\hline CR5 & $-0.224 *$ & 0.068 & 0.022 & $0.847 *$ & 1 & & \\
\hline VR1 & -0.031 & $0.118^{*}$ & 0.019 & $0.812^{*}$ & $0.710^{*}$ & 1 & \\
\hline VR5 & $-0.119 *$ & $0.102 *$ & 0.014 & $0.678 *$ & $0.835^{*}$ & $0.817 *$ & 1 \\
\hline Vote-differentiation & $0.082 *$ & $0.071 *$ & -0.049 & -0.053 & 0.033 & $0.310 *$ & $0.422 *$ \\
\hline
\end{tabular}

* indicates significance at 5 percent.

Naturally all ownership variables display high and significant correlations. Sales are negatively correlated with all ownership variables, but weaker for VRI and VR5 than with CRI and CR5. In other words, ownership concentration measured by cash-flow rights is inversely related to firm size. This means that controlling owners remain in large firms by resorting to dual-class equity structure. Consistent with this, investments are significantly correlated with control rights and vote-differentiation, but not with cash-flow rights.

In order to control for unobserved, time-invariant, heterogeneity across firms fixed effect model with firm) and time effects is applied. The fixed time effect is motivated by the efficient markets hypothesis; in any single period a firm may be under or overvalued but over time this error is expected to be zero. The firm fixed effects controls for differences in depreciation rates across firms and industries. 
To identify non-linear effect on performance the ownership variables are also estimated in quadratic and cubic form. In table $7 \mathrm{a}$ and b merely 3 out of 24 estimated ownership parameters are significant. However, a deviation from one-share-one-vote creates large negative effects.

Table 7a, Concentration of cash-flow rights and performance

\begin{tabular}{l|cllllll}
\multicolumn{1}{l}{ Dependent variable: $\left(\mathbf{M}_{\mathbf{t}}-\mathbf{M}_{\mathbf{t}-1}\right) / \mathbf{M}_{\mathbf{t}-1}$} \\
\hline
\end{tabular}

$*, * *$ and $* * *$ indicates significance at 10,5 and 1 percent respectively. $\mathrm{t}$-values in brackets.

Firms with only a single class of equity do not significantly underperforms, i.e. $q_{m}$ not different from one, whereas firms that rely on dual-class equity shares on average have a return on dualclass shares that is 30 percent below the opportunity cost of capital. 
Table 7b, Concentration of control/voting rights and performance

\begin{tabular}{|c|c|c|c|c|c|c|}
\hline \multicolumn{7}{|c|}{ Dependent variable: $\left(\mathrm{M}_{\mathrm{t}}-\mathrm{M}_{\mathrm{t}-1}\right) / \mathrm{M}_{\mathrm{t}-1}$} \\
\hline & Equation B & Equation $\mathrm{C}$ & Equation D & Equation $\mathbf{E}$ & Equation $\mathbf{F}$ & Equation G \\
\hline Constant, - $\delta$ & $\begin{array}{l}-0.088 * * * \\
(-3.80)\end{array}$ & $\begin{array}{c}-0.085^{* * * *} \\
(-3.69)\end{array}$ & $\begin{array}{l}-0.084 * * * \\
(-3.63)\end{array}$ & $\begin{array}{l}-0.085^{* * *} \\
(-3.72)\end{array}$ & $\begin{array}{l}-0.089^{* * * *} \\
(-3.86)\end{array}$ & $\begin{array}{l}-0.090^{* * *} \\
(-3.90)\end{array}$ \\
\hline $\mathbf{I}_{\mathbf{t}} / \mathbf{M}_{\mathrm{t}-1}$ & $\begin{array}{l}0.911 * * * \\
(9.56)\end{array}$ & $\begin{array}{l}0.818 * * * \\
(6.02)\end{array}$ & $\begin{array}{l}0.709 * * * \\
(3.60)\end{array}$ & $\begin{array}{l}0.702 * * * \\
(5.51)\end{array}$ & $\begin{array}{l}0.966^{* * * *} \\
(4.29)\end{array}$ & $\begin{array}{l}0.649^{*} \\
(1.82)\end{array}$ \\
\hline $\begin{array}{l}\text { Dual-class } \\
\text { Shares }\end{array}$ & $\begin{array}{l}-0.317 * * * \\
(-3.62)\end{array}$ & $\begin{array}{l}-0.317 * * * \\
(-3.61)\end{array}$ & $\begin{array}{l}-0.331 * * * \\
(-3.69)\end{array}$ & $\begin{array}{c}-0.390 \\
(-4.19)\end{array}$ & $\begin{array}{l}-0.396 * * * \\
(-4.26)\end{array}$ & $\begin{array}{l}-0.404 * * * \\
(-4.33)\end{array}$ \\
\hline VR1 & $\begin{array}{r}0.001 \\
(0.24)\end{array}$ & $\begin{array}{r}0.007 \\
(0.99)\end{array}$ & $\begin{array}{r}0.022 \\
(1.07)\end{array}$ & & & \\
\hline $\mathrm{VR1}^{2}$ & & $\begin{array}{c}-0.001 \\
(-0.96)\end{array}$ & $\begin{array}{c}-0.001 \\
(-0.92)\end{array}$ & & & \\
\hline$V_{R} 1^{3}$ & & & $\begin{array}{c}0.000 \\
(0.76)\end{array}$ & & & \\
\hline VR5 & & & & $\begin{array}{l}0.005^{* *} \\
(2.03)\end{array}$ & $\begin{array}{c}-0.007 \\
(-0.82)\end{array}$ & $\begin{array}{r}0.021 \\
(0.80)\end{array}$ \\
\hline $\mathrm{VR5}^{2}$ & & & & & $\begin{array}{c}0.000 \\
(1.42)\end{array}$ & $\begin{array}{c}-0.001 \\
(-0.92)\end{array}$ \\
\hline $\mathrm{VR5}^{3}$ & & & & & & $\begin{array}{l}0.000 \\
(1.15)\end{array}$ \\
\hline No. obs. & 794 & 794 & 794 & 794 & 794 & 794 \\
\hline No. firms & 142 & 142 & 142 & 142 & 142 & 142 \\
\hline F-value & 12.38 & 12.12 & 11.86 & 12.54 & 12.32 & 12.08 \\
\hline $\mathbf{R}^{2}$ & 0.42 & 0.42 & 0.42 & 0.42 & 0.42 & 0.42 \\
\hline Average $q_{m}$ & 0.812 & 0.836 & 0.836 & 0.774 & 0.728 & 0.730 \\
\hline Dual-class $q_{m}$ & 0.612 & 0.657 & 0.665 & 0.564 & 0.514 & 0.512 \\
\hline Single-class $q_{m}$ & 0.929 & 0.988 & 0.982 & 0.954 & 0.910 & 0.916 \\
\hline
\end{tabular}

The fact that vote-differentiation has a significant negative effect on firm performance indicates that the ownership-performance relationship may differ between firms with one class of shares and those having separated cash-flow rights and control rights. This negative effect increases in equation $A$ trough $G$, when the ownership variables are added. One possible interpretation is that the ownership variables are picking up positive incentive effect. This in turn suggests that the ownership effects differ between the two categories of firms.

In table 6 ownership variables are interacted with the dummy variable for dual-class share structure (one for vote-differentiation and zero for single class share structure). Different specifications of the functional form have been estimated. The results are relatively robust with respect to choice between fixed effect, random effect or simply pooled OLS model. A previous study has also found estimates of $q_{m}$ to be stable to model specification (Bjuggren et al. (2006)). 
Table 8a, Dual-class shares, ownership and performance

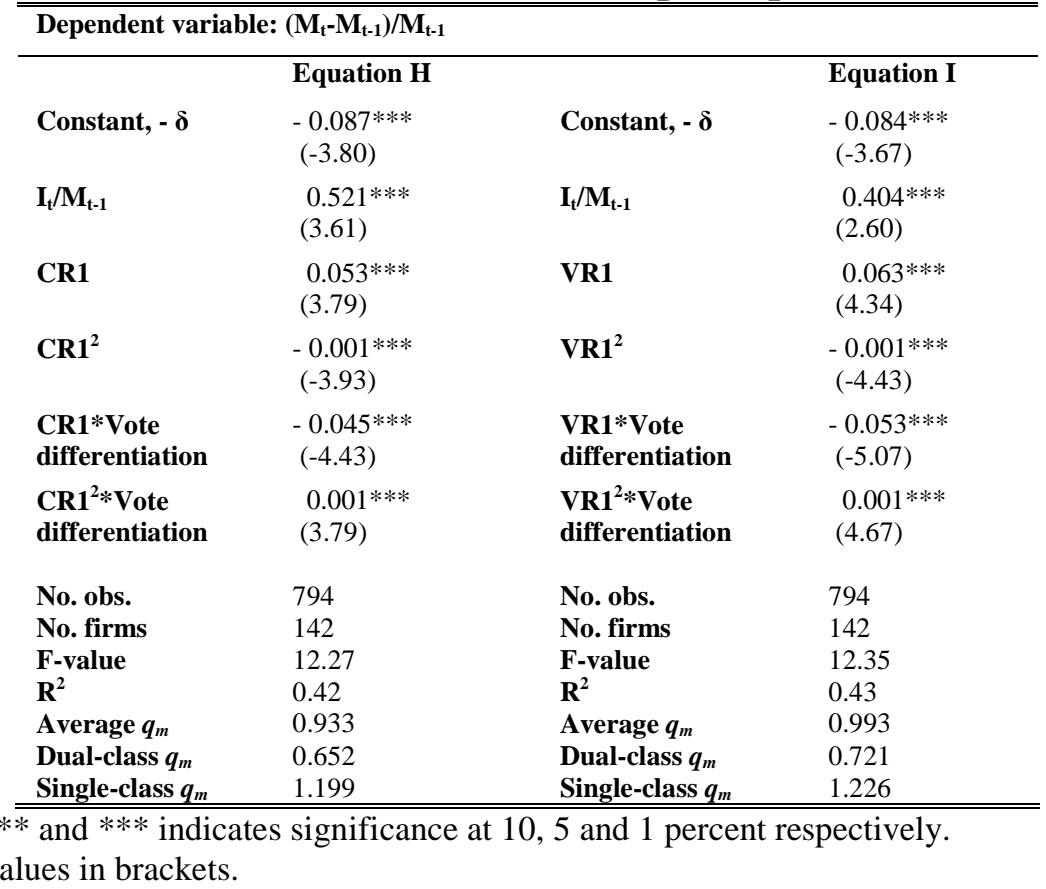

\section{Table 8b, Dual-class shares, ownership and performance}

\begin{tabular}{|c|c|c|c|}
\hline \multicolumn{4}{|c|}{ Dependent variable: $\left(\mathrm{M}_{\mathrm{t}}-\mathrm{M}_{\mathrm{t}-1}\right) / \mathbf{M}_{\mathrm{t}-1}$} \\
\hline & Equation $\mathbf{H}$ & & Equation I \\
\hline Constant, - $\delta$ & $\begin{array}{l}-0.091 * * * \\
(-3.93)\end{array}$ & Constant, $-\delta$ & $\begin{array}{l}-0.092 * * * \\
(-3.99)\end{array}$ \\
\hline $\mathbf{I}_{\mathbf{t}} / \mathbf{M}_{\mathrm{t}-1}$ & $\begin{array}{r}0.336 \\
(0.89)\end{array}$ & $\mathbf{I}_{\mathbf{t}} / \mathbf{M}_{\mathrm{t}-1}$ & $\begin{array}{r}0.050 \\
(0.12)\end{array}$ \\
\hline CR5 & $\begin{array}{l}0.067 * * \\
(2.06)\end{array}$ & VR5 & $\begin{array}{l}0.089 * * * \\
(2.64)\end{array}$ \\
\hline $\mathrm{CR5}^{2}$ & $\begin{array}{l}-0.002^{* *} \\
(-2.31)\end{array}$ & $\mathrm{VR5}^{2}$ & $\begin{array}{l}-0.002 * * * \\
(-2.84)\end{array}$ \\
\hline $\mathrm{CR5}^{3}$ & $\begin{array}{l}0.000 * * * \\
(2.45)\end{array}$ & $\mathrm{VR5}^{3}$ & $\begin{array}{l}0.000 * * * \\
(2.94)\end{array}$ \\
\hline $\begin{array}{l}\text { CR5*Vote } \\
\text { differentiation }\end{array}$ & $\begin{array}{l}-0.060 * * * \\
(-3.24)\end{array}$ & $\begin{array}{l}\text { VR5*Vote } \\
\text { differentiation }\end{array}$ & $\begin{array}{l}-0.094 * * * \\
(-3.89)\end{array}$ \\
\hline $\begin{array}{l}\text { CR5 }^{2 *} \text { Vote } \\
\text { differentiation }\end{array}$ & $\begin{array}{l}0.002 * * * \\
(2.82)\end{array}$ & $\begin{array}{l}\text { VR5 }^{2 *} \text { Vote } \\
\text { differentiation }\end{array}$ & $\begin{array}{l}0.003 * * * \\
(3.55)\end{array}$ \\
\hline $\begin{array}{l}\mathrm{CR5}^{3 *} \text { *Vote } \\
\text { differentiation }\end{array}$ & $\begin{array}{l}-0.000 * * * \\
(-2.65)\end{array}$ & $\begin{array}{l}\mathrm{VR5}^{3} * \text { Vote } \\
\text { differentiation }\end{array}$ & $\begin{array}{l}-0.000 * * * \\
(-3.37)\end{array}$ \\
\hline No. obs. & 794 & No. obs. & 794 \\
\hline No. firms & 142 & No. firms & 142 \\
\hline F-value & 11.58 & F-value & 11.91 \\
\hline $\mathbf{R}^{2}$ & 0.42 & $\mathbf{R}^{2}$ & 0.43 \\
\hline Average $q_{m}$ & 0.808 & Average $q_{m}$ & 0.889 \\
\hline Dual-class $q_{m}$ & 0.656 & Dual-class $q_{m}$ & 0.784 \\
\hline Single-class $q_{m}$ & 0.952 & Single-class $q_{m}$ & 0.978 \\
\hline
\end{tabular}

$*, * *$ and $* * *$ indicates significance at 10,5 and 1 percent respectively.

$\mathrm{t}$-values in brackets. 
The results are robust with respect to the choice between simple pooled OLS with year dummies, fixed effect model with year and firm effects and random effects model. The estimates are robust with respect to model specification. Since the number of firms with available ownership data is limited to 143, the firm effects affectively captures any industry effects. Consequently, all equation shave been estimated with two digit industry SIC codes.

The stock market may in any single period be under- or overestimated, but for a longer period of time the expected error in stock market evaluations is zero, $E\left(\mu_{t}\right)=0$. To control for this possibility annual dummy variables are included and estimated under the restriction that they summarize to zero. Annual deviations in stock market evaluations are therefore measured as deviations from the average. To control for the possibility that the Scandinavian countries have systematic differences in returns, country dummies are also included. These are also estimated under the restriction that they summarize to zero, so that any deviation is measured as the deviation from the Scandinavian average. Time, industry and country effect are not reported.

Hypothesis 1 and 2 (HI and H2) can not be rejected. For all measures of ownership concentration $(C R 1, C R 5, V R I$ and $V R 5)$ a positive non-linear relationship is found. In firms with one-shareone-vote increasing ownership has a positive but marginally diminishing effect on performance. For the two concentration measure of the single largest owner, $C R 1$ and VRl, a quadratic form gives the best fit, whereas for the concentration of the five largest owners, CR5 and VR5, a cubic form provides the best fit.

The average $q_{m}$ for single class equity firms lie between 0.95 and $1.23^{13}$. In firms with votedifferentiated shares the effects are similar but much weaker. By comparing the parameters in equations $H$ and $I$ in table 8 a and b one can see that in vote-differentiated firms the positive effect of ownership concentration is significantly lower compared to other firms. Average $q_{m}$ 's estimate for firms with dual-share class structure lie between 0.65 and 0.78 (equation $H$ and $I$ respectively). As in equation $A$, firms with dual-class shares seem to be investing at approximately 30 percent below their cost of capital. From equation $\mathrm{H}$ and $\mathrm{I}$ in table $8 \mathrm{a}$ and $\mathrm{b}$ it

\footnotetext{
${ }^{13}$ The marginal effects have been calculated based on the average ownership concentration in the data set. $(\mathrm{CR} 1=$ 22.24, CR5 = 44.52, VR1 = 28.58 and VR5 = 52.85).
} 
is clear that the separation cash-flow and control rights reduces the positive effect of ownership and enhance the entrenchment effect. Examining listed firms in Sweden, Bjuggren et al. (2006) find similar negative effect of vote-differentiation and positive effect of ownership concentration on investment performance of firms.

Controlling for ownership characteristics and dual-class equity weakens the country effects (not reported here), but remains significantly negative for Sweden and positive for Norway. However the effects of ownership and deviations from one-share-one-vote cut across national boundaries.

The intercept will as, discussed in section 2, capture both the depreciation rate and any systematic changes in market evaluations. In equation $A$ to $I$ the intercept is estimated to approximately 9 percent. This is a reasonable estimate and is in line with previous estimates of depreciation rates. Furthermore, the intercept dose not affect the marginal effect, thus not of any importance for the interpretation of the results. 
This paper examines the linkage between corporate investments, returns and ownership structure in the Scandinavian countries. Marginal $q$ is used as performance measure. Marginal $q$ measures the marginal return on capital relative its cost of capital. This return to cost of capital ratio $(r / i=$ $q_{m}$ ) is a measure of what Tobin (1982) labeled the functional efficiency of capital markets. When studying firm performance this method has some clear advantages over the conventional market to book measures of Tobin's average $q$.

Few Scandinavian firms can be characterized as having dispersed ownership as described by Berle and Means (1932). Vote-differentiation is a common tool for creating and maintaining strong and concentrated ownership structures. Scandinavian firms make more frequent use of control mechanisms than firms in comparable countries. On average the largest owner holds more than 20 percent of the capital $(C R l)$ and close to 30 percent of the vote rights $(V R l)$.

The hypothesis that ownership concentration improves resource allocation by reducing agency problems is supported in this paper. The effect of ownership on investment performance is however found to be non-liner; cubic or quadratic form. This is consistent with the entrenchment hypothesis. Strong support of the hypothesis that control mechanisms are detrimental to firm performance is found.

Ownership concentration is found to have a non-linear effect on firm performance. This is consistent with previous studies that both find positive incentive effects and negative entrenchment effect of ownership concentration. For firms with one-share-one-vote ownership has a positive impact but marginally diminishing, whereas for firms controlled by dual-class shares this effect is weaker, and have a systematically worse performance. Firms with votedifferentiated shares are found to have a systematically worse performance as compared to firms with one single class of shares. Dual-class shares drive a wedge between cash-flow rights and control rights. Not only does this change the control structure, but it also changes the incentive structure. Firms with only one equity class are on average investing efficiently, whereas firm with dual-class equity structure are over investing. The separation of cash-flow rights and control 
rights reduces the positive incentive effect and enhances the negative entrenchment effect. By impairing capital reallocation corporate control mechanisms are in the long run going to be harmful for industry dynamics and economic renewal.

Vote-differentiation creates massive entrenchment effects and destroys large values that in the long-run are likely to be detrimental to the functional efficiency of the Scandinavian capital markets. On average these firms have returns on investments that are approximately 30 percent below their cost of capital.

Differences in investment performance across firms can largely be explained by differences in ownership structure and in particular to what extent corporate control is upheld by dual-class equity structure. Separation of cash-flow rights from control appears to distort the incentives of the controlling owner by significantly reducing the incentive effect. These results appear to be inconsistent with the legal origin hypothesis. 


\section{References}

Baumol, W. J., Heim, P., Malkiel, B. G. \& Quandt, R. E., (1970), "Earnings Retention, New Capital and the Growth of the Firm," Review of Economics and Statistics, 345-355.

Bebchuk, L., Kraakman, R. \& Triantis, G., (1999), Stock Pyramids, Cross-Ownership, and DualClass Equity: The Creation and Agency Costs of Separating Control from Cash Flow Rights. NBER Working Paper, No. 6951.

Bennedsen M. B., \& Nielsen, K. M., (2005), "The principle of Proportionality: Separating the Impact of Dual Class Shares, Pyramids and Cross-ownership on Firm Value Across Legal Regimes in Western Europe," Center for Industrial Economics Discussion papers, University of Copenhagen.

Berle, A. A. \& Means, G., (1932), The Modern Corporation and Private Property, The Macmillan Company, New York.

Bergström, C. \& Rydqvist, K., (1990), “Ownership of equity in dual-class firms,” Journal of Fiancial Economics, 14, 255-269.

Bjuggren, P-O., Eklund, J., E., \& Wiberg, D., K., (2007), “Ownership Structure, Control and Firm Performance: the Effects of Vote Differentiated Shares." Forthcoming: Applied Financial Economics.

Bjuggren, P-O. \& Wiberg, D., (2006), "Industry Specific Effects in Investment Performace and Valuation of Firms; Marginal $q$ in a Stock Market Bubble," Forthcoming: Empirica.

Bøhren, Ø, \& Ødegaard, A. B., (2005), "Governance and performance revisited," Forthcoming in: Gregouriu, G., \& Ali, P., (ed), International Corporate Goverance after Sarbanes-Oxley, Wiley.

Carsten, G., (1993), "Europäische Integration und Nordische Zusammenarbeit auf dem Gebiet des Zivilrechts,“ Zeitschrift für Europäisches Privatrecht, 335.

Cho, M-H., (1998), "Ownership Structure, Investments, and the Corporate Value: An Empitical Analysis", Journal of Financial Economics, vol. 47, no.1, 103-121.

Demsetz, H., (1983), "The Structure of Ownership and the Theory of the Firm", Journal of Law and Economics, vol. 26, no. 2, 375-390.

Demsetz, H. \& Lehn, K., (1985), "The Structure of Corporate Ownership: Causes and Consequences," Journal of Political Economy, vol. 93, no. 6, 1155-1177.

Demsetz, H. \& Villalonga, B., (2001), "Ownership Structure and Corporate Performance," Journal of Corporate Finance, 7, 209-233. 
Denis, D. K. \& McConnell, (2003), "International Corporate Governance," Journal of Financial and Quantitative Analysis, vol. 38, no. 1, 1-36.

Faccio, M. \& Land L.H.P., (2002), "The ultimate ownership of Western European corporations," Journal of Financial Economics, 65, 365-395.

Gugler, K., \& Yurtoglu, B. B, (2003), "Average q, marginal q, and the relation between ownership and performance." Economics Letters, 78, 379-384.

Gugler, K., Mueller, D. C. \& Yurtoglu, B. B., (2002), ”Corporate Goverance, Capital Market Discipline and Return on Investments," miemo Universty of Vienna.

Hayashi, F., (1982), "Tobin's Marginal q and Average q: A Neoclassical Interpretation," Econometrica, vol. 50, no. 1, 213-224.

Henrekson, M. \& Jakobsson, U., (2006), Den svenska modellen för företagsägande och företagskontroll vid skiljevägen, Institutet för näringslivsforskning, Policy Paper No. 1, Stockholm.

Högfeldt, P., (2004), The History of Politics of Corporate Ownership in Sweden, NBER Working Paper No. 10641.

Jensen, J. \& Meckling, W., (1976), "Theory of the firm; managerial behavior, agency costs and ownership structure," Journal of Financial Economics, no. 3 305-360.

La Porta, R., Lopez-de-Silanes, F. \& Shleifer, A., (1999), "Corporate Ownership around the World," Journal of Finance, vol. 54, no. 2, 471-517.

La Porta, R., Lopez-de-Silanes, F., Shleifer, A. \& Vishny, R. W., (1998), "Law and Finance," Journal of Political Economy, vol. 106, no. 6, 1113-1155.

La Porta, R., Lopez-de-Silanes, F., Schleifer, A. \& Vishny, R. W., (1997), "Legal Determinats of External Finance," Journal of Finance, vol. 52, no. 3, 1131-1150.

Manne, H., (1965), "Mergers and the Market for Corporate Control," Journal of Political Economy, 75:110-26.

Marris, R., (1964), The Economic Theory of Managerial Capitalism, New York: Free Press.

Morck, R., Schleifer, A. \& Vishny, R., (1988), Management Ownership and Market Valuation: An Empirical Analysis," Journal of Financial Economics, 20, 293-315.

Morck, R., Wolfenzon, D. and Yeung, B., (2005), "Corporate Governance, Economic, Entrenchment, and Growth," Journal of Economic Literature, 43:655-720.

Mueller, D. C., (2003), The Corporation; Investments, mergers and growth, Routledge. 
Mueller, D. C. \& Reardon, E. A., (1993), "Rates of Return on Corporate Investment," Southern Economic Journal, vol. 60, no. 2, 430-453.

Roe, M. J., (2003), Political Determinants of Corporate Governance, Oxford University Press, Oxford.

Shleifer, A. \& Vishny, R. W., (1997), "A Survey of Corporate Governance," Journal of Finance, vol. 52, no. 2, 737-783.

Smith, A., (1776), An Inquiry into the Nature and Causes of the Wealth of Nations. Modern Library (2000), New York.

Söderström, H. T., (eds.) Berglöf, E., Holmström B., Högfeldt, P., \& Mayersson Milgrom, E. M., (2003), Ägarmakt och omvandling - Den svenska modellen utmanad, Ekonomirådets rapport 2003, SNS, Stockholm.

Tobin, J., (1982), “On the Efficiency of Financial Systems,” Lloyd's Banking Review. 153, 1-15.

Veblen, T., (1921), The Engineers and the Price System, New York, Viking. 


\section{Appendix 1 Marginal $q$}

Figure 1 Marginal rate of return on capital, $m r r$, cost of capital, $i$, and marginal q

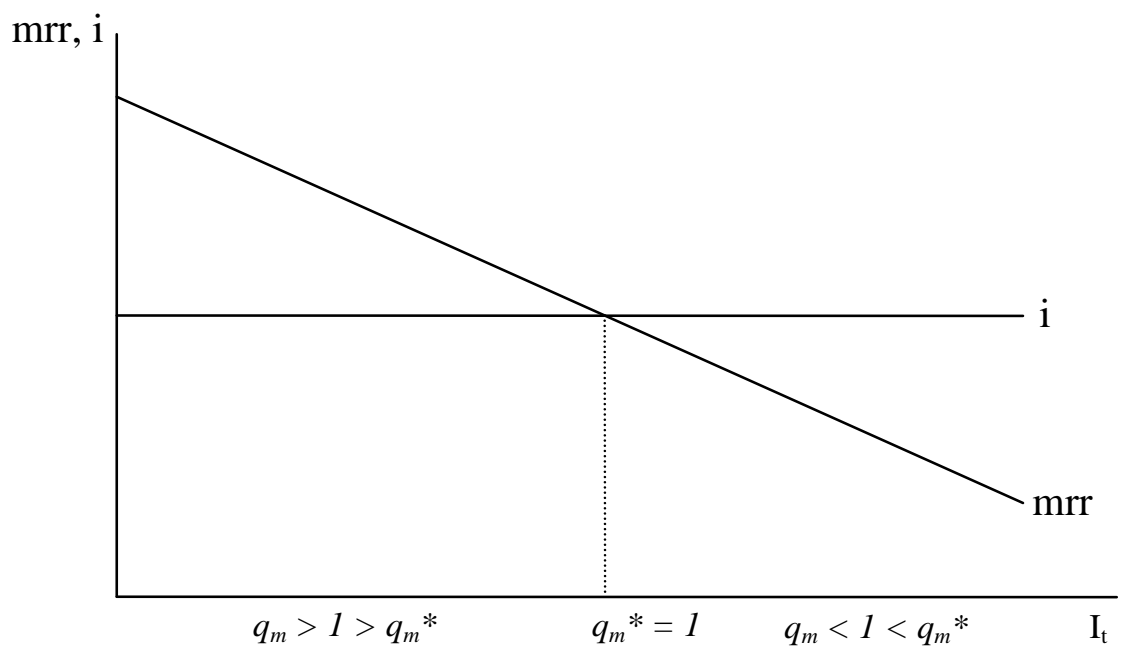

Figure 2 Marginal q

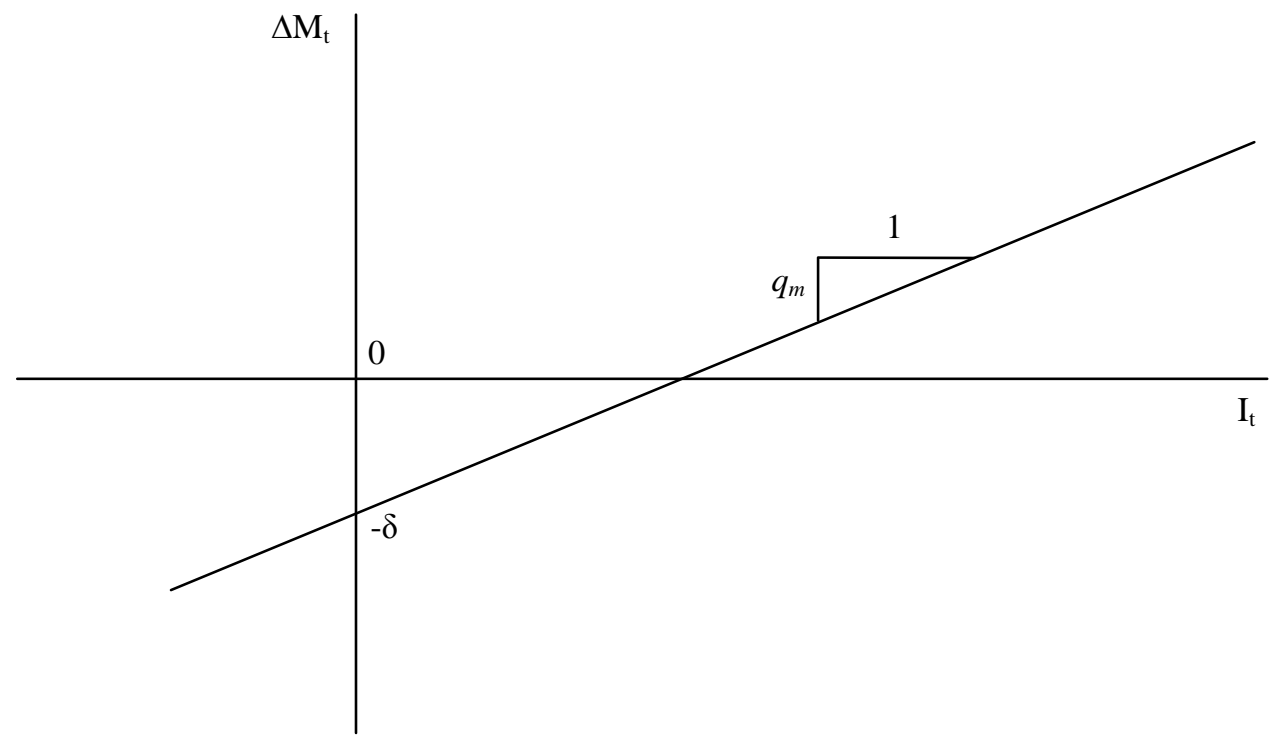




\section{Appendix 2 Ownership structure}

\section{Denmark}

\begin{tabular}{llcccc}
\hline \hline All firms & & & & & \\
\hline & Mean & Std. div. & Min & Max & No. firms \\
CR 1 & 23.9 & 14.4 & 1.0 & 51.7 & 10 \\
CR 3 & 35.4 & 16.6 & 3.0 & 52.1 & 10 \\
CR 5 & 37.4 & 17.6 & 5 & 60.0 & 10 \\
& & & & & \\
VR 1 & n.a. & n.a. & n.a. & n.a. & 10 \\
VR 3 & n.a. & n.a. & n.a. & n.a. & 10 \\
VR 5 & n.a. & n.a. & n.a. & n.a. & 10
\end{tabular}

Vote-differentiated firms

\begin{tabular}{lccllc}
\hline & Mean & Std. div. & Min & Max & No. firms \\
CR 1 & n.a. & n.a. & n.a. & n.a. & 2 \\
CR 3 & n.a. & n.a. & n.a. & n.a. & 2 \\
CR 5 & n.a. & n.a. & n.a. & n.a. & 2 \\
& & & & & \\
VR 1 & n.a. & n.a. & n.a. & n.a. & 2 \\
VR 3 & n.a. & n.a. & n.a. & n.a. & 2 \\
VR 5 & n.a. & n.a. & n.a. & n.a. & 2
\end{tabular}

Firms with one-share-one-vote

\begin{tabular}{lccllc}
\hline & Mean & Std. div. & Min & Max & No. firms \\
CR 1 & n.a. & n.a. & n.a. & n.a. & 8 \\
CR 3 & n.a. & n.a. & n.a. & n.a. & 8 \\
CR 5 & n.a. & n.a. & n.a. & n.a. & 8 \\
& & & & & \\
VR 1 & n.a. & n.a. & n.a. & n.a. & 8 \\
VR 3 & n.a. & n.a. & n.a. & n.a. & 8 \\
VR 5 & n.a. & n.a. & n.a. & n.a. & 8 \\
\hline \hline
\end{tabular}

\section{Finland}

\begin{tabular}{llcccc}
\hline \hline All firms & & & & & \\
\hline & Mean & Std. div. & Min & Max & No. firms \\
CR 1 & 20.3 & 15.6 & 0.4 & 62.2 & 55 \\
CR 3 & 31.7 & 17.6 & 1.1 & 72.5 & 55 \\
CR 5 & 37.1 & 18.1 & 1.5 & 79.1 & 55 \\
& & & & & \\
VR 1 & 23.8 & 19.3 & 0.4 & 84.1 & 55 \\
VR 3 & 37.1 & 22.5 & 1.1 & 87.9 & 55 \\
VR 5 & 43.0 & 22.9 & 1.5 & 89.8 & 55
\end{tabular}

Vote-differentiated firms

\begin{tabular}{llcccc}
\hline & Mean & Std. div. & Min & Max & No. firms \\
CR 1 & 20.4 & 12.1 & 2.93 & 38.6 & 14 \\
CR 3 & 33.4 & 14.3 & 6.4 & 53.9 & 14 \\
CR 5 & 39.3 & 14.5 & 9.4 & 57.5 & 14 \\
& & & & & \\
VR 1 & 34.2 & 22.9 & 4.6 & 84.1 & 14 \\
VR 3 & 54.6 & 24.1 & 12.1 & 87.9 & 14 \\
VR 5 & 62.2 & 22.4 & 18.6 & 89.8 & 14
\end{tabular}

Firms with one-share-one-vote

\begin{tabular}{llcccc}
\hline & Mean & Std. div. & Min & Max & No. firms \\
CR 1 & 20.3 & 16.7 & 0.4 & 62.2 & 41 \\
CR 3 & 31.1 & 18.7 & 1.1 & 72.5 & 41 \\
CR 5 & 36.4 & 19.3 & 1.5 & 79.1 & 41 \\
& & & & & \\
VR 1 & 20.3 & 16.7 & 0.4 & 62.2 & 41 \\
VR 3 & 31.1 & 18.7 & 1.1 & 72.5 & 41 \\
VR 5 & 36.4 & 19.3 & 1.5 & 79.1 & 41 \\
\hline \hline
\end{tabular}




\section{Norway}

\begin{tabular}{llcccc}
\hline \hline All firms & & & & & \\
\hline & Mean & Std. div. & Min & Max & No. firms \\
CR 1 & 28.6 & 16.6 & 7.2 & 68.9 & 40 \\
CR 3 & 48.3 & 22.0 & 17.4 & 93.8 & 40 \\
CR 5 & 56.0 & 21.4 & 22.7 & 95.1 & 40 \\
& & & & & \\
VR 1 & 29.0 & 16.7 & 7.2 & 68.9 & 40 \\
VR 3 & 48.9 & 22.5 & 17.4 & 93.8 & 40 \\
VR 5 & 56.5 & 21.8 & 22.7 & 96.5 & 40
\end{tabular}

Vote-differentiated firms

\begin{tabular}{|c|c|c|c|c|c|}
\hline & Mean & Std. div. & Min & $\operatorname{Max}$ & No. firms \\
\hline CR 1 & 30.4 & 10.7 & 15.3 & 40.0 & 4 \\
\hline CR 3 & 66.0 & 24.0 & 34.1 & 87.8 & 4 \\
\hline CR 5 & 74.7 & 22.6 & 44.8 & 93.8 & 4 \\
\hline VR 1 & 34.1 & 10.9 & 18.5 & 43.1 & 4 \\
\hline VR 3 & 72.0 & 22.4 & 42.2 & 91.3 & 4 \\
\hline VR 5 & 80.0 & 20.9 & 52.3 & 96.5 & 4 \\
\hline \multicolumn{6}{|c|}{ Firms with one-share-one-vote } \\
\hline & Mean & Std. div. & Min & $\operatorname{Max}$ & No. firms \\
\hline CR 1 & 28.4 & 17.3 & 7.2 & 68.9 & 36 \\
\hline CR 3 & 46.3 & 21.2 & 17.4 & 93.8 & 36 \\
\hline CR 5 & 53.9 & 20.5 & 22.7 & 95.1 & 36 \\
\hline VR 1 & 28.4 & 17.3 & 7.2 & 68.9 & 36 \\
\hline VR 3 & 46.3 & 21.2 & 17.4 & 93.8 & 36 \\
\hline VR 5 & 53.9 & 20.5 & 22.7 & 95.1 & 36 \\
\hline
\end{tabular}

\section{Sweden}

\begin{tabular}{|c|c|c|c|c|c|}
\hline \multicolumn{6}{|c|}{ All firms } \\
\hline & Mean & Std. div. & Min & Max & No. firms \\
\hline CR 1 & 22.9 & 14.9 & 4.2 & 82.4 & 110 \\
\hline CR 3 & 37.7 & 17.9 & 9.8 & 90.0 & 110 \\
\hline CR 5 & 44.9 & 18.2 & 13.4 & 93.8 & 110 \\
\hline VR 1 & 32.5 & 20.7 & 4.2 & 89.3 & 109 \\
\hline VR 3 & 49.2 & 22.3 & 10.2 & 93.7 & 109 \\
\hline VR 5 & 55.8 & 21.6 & 14.0 & 95.3 & 109 \\
\hline \multicolumn{6}{|c|}{ Vote-differentiated firms } \\
\hline & Mean & Std. div. & Min & Max & No. firms \\
\hline CR 1 & 24.1 & 14.3 & 5.2 & 60.4 & 70 \\
\hline CR 3 & 40.0 & 18.4 & 9.8 & 80.3 & 70 \\
\hline CR 5 & 47.4 & 18.6 & 13.4 & 86.6 & 70 \\
\hline VR 1 & 39.2 & 20.4 & 9.5 & 89.3 & 68 \\
\hline VR 3 & 58.3 & 20.3 & 18.4 & 93.7 & 68 \\
\hline VR 5 & 64.5 & 19.3 & 20.7 & 95.3 & 68 \\
\hline \multicolumn{6}{|c|}{ Firms with one-share-one-vote } \\
\hline & Mean & Std. div. & Min & Max & No. firms \\
\hline CR 1 & 20.7 & 16.0 & 4.2 & 82.4 & 40 \\
\hline CR 3 & 33.6 & 16.5 & 10.2 & 90.0 & 40 \\
\hline CR 5 & 40.7 & 17.0 & 14.0 & 93.8 & 40 \\
\hline VR 1 & 20.7 & 16.0 & 4.2 & 82.4 & 40 \\
\hline VR 3 & 33.6 & 16.5 & 10.2 & 90.0 & 40 \\
\hline VR 5 & 40.7 & 17.0 & 14.0 & 93.8 & 40 \\
\hline
\end{tabular}

